\title{
Examination of the Relationship between Eighth Grade Students' Learning Styles and Attitudes towards Mathematics
}

\author{
Bünyamin Aydın \\ Correspondence: Bünyamin Aydın, Necmettin Erbakan University, Ahmet Keleşoğlu Faculty of Education, Meram, \\ Konya, Turkey
}

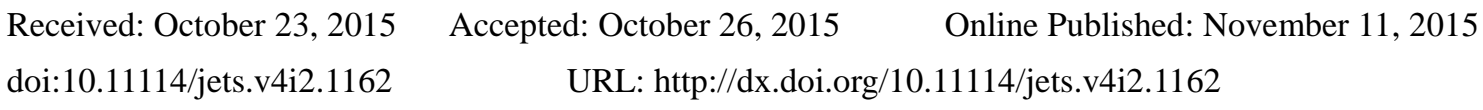

\begin{abstract}
The aim of this research is to determine eighth grade students' learning styles and attitudes toward math class and to show the relationship between their learning styles and attitudes toward math class. Sample of the research consists of 100 eighth grade students having education in a school in the Central Anatolia of our country. As data collection tool, Kolb Learning Style Inventory and attitude scale toward math class. According to the data obtained, it has been seen that attitude level to math lesson of eighth grade students who have participated in the research and their learning style are related.
\end{abstract}

Keywords: learning style, attitude toward math class, eighth grade students

\section{Introduction}

\subsection{Introduce the Problem}

Math has always been a nightmare to many individuals from the first stage of their educations, because math class is seen as hard and boring by students and a lesson which is hard to teach and to which student interest is low (Öcalan, 2004; Peker \& Mirasyedioğlu, 2003). Role of attitudes is very big in whether students succeed or fail in math or they like math (Çoban, 1989).

Attitudes are psychological structures which are among affective behaviours and cannot be directly observed (Aşkar, 1986). Attitude toward math class is defined by Neale (1969) as "it is total of whether the person like math or not, the attitude to engage in mathematical activities or avoid them, person's belief for him/her to be good or bad in math and his/her belief in whether math shall be benefit or not" (Cited in Akgün, 2002).

Leaning process is not same for every individual. Kolb (1984) defined learning styles as the method preferred by someone in perceiving and processing the information. This definition consists of his four stage experiential learning cycle. Kolb gives the definition of experimental learning regarding with where the information is created within the processing cycle of the life (Chen, Toh \& Ismail, 2005).

Kolb Learning Style Inventory has been separated from the other personality and learning style tests and used in education based on the experiential learning and development theory. This theory shows the level of learning processes compared to each other and their generalizable tendency differences. Concrete experience forms basis for observation and reflection in cyclical learning process consisting of four stages. These observations are resembled to the theories by new application from which results can be obtained. These applications provide service as guide to establish new experiences. Thus, cycle is formed. Being an effective learner requires to show the skills in two opposite poles (De Bello, 1990: 203).

Special ways followed by the individual in this learning form the learning styles. It is the innate characteristic which affects the success of the person. The concept of learning styles has first been asserted by Rita Dunn in 1960. She has defined learning styles as "Different and special ways used by each student when getting prepared to learn, learning, and remembering a new and difficult information" (Cited in Boydak, 2001). Kolb describes it as "way preferred by the individual in perceiving and processing the information". McCarthy (1987) expresses it as "preference of individuals in using their skills of perceiving and processing the information".

Various models have been established on learning styles. Those used most among these models are those realized by Kolb, McCarthy, Jung, Within, Dunn, Reid, and Grasha (Hall, 1993). In the experiential learning model realized by 
Kolb, Kolb has defended that individuals learn with their own experiences. In this model, learning styles are in a cycle and learning styles of individuals are determined based on their way of processing and obtaining the information. Then, Kolb separates individuals into four different groups based on the score they gained from the learning style scale which he developed. These groups consist of their combination based on the learning styles of the individuals. These groups are Diverging (divergent thinkers, who diverges), Assimilating (who assimilates), Converging (convergent thinkers, who converges), and Accommodating (regulatory, establisher) (Ülgen, 1994; Akkoyunlu, 1995).

1. Diverging: These individuals obtain information in abstract conceptualization stage and form them in active trying stage. They try to find practical applications of thoughts and ideas. They focus on solving problem and they like situations which have only a single correct answer. They prefer to interest in objects rather than individuals. As mentioned by Kolb, they prefer having a career in technical areas.

2. Assimilating: These individuals obtain information in abstract conceptualization stage and form them in observation - reflection stage. In development of theoretical models such as assimilating of their own experiences and observations in form of understanding, they use logical reasoning with the way of induction. As mentioned by Kolb, they prefer working in areas in direction of research.

3. Converging: These individuals comprehend information with concrete experience and form them in the stage of observation and reflection. They are more successful in observing concrete situation in different point of view and interpreting and arranging them into more meaningful situations. They are known to be imaginative. They are individuals who care their senses and have wide range of field of interest. They prefer having career theoretical development and attorney.

4. Accommodation: Individuals obtain the information by concrete experiences and form it with the way of active trying. They are inclined to trial and error. They collect information from others and remove the unrealistic theories by considering them unnecessary. They prefer having career in business world.

It is not correct to make a classification between learning styles such as the best or the most correct, because the important thing here is to determine the dominant and non-dominant learning styles of the individual. Also, according to Kolb (1984) and McCarthy (1987), learning style consists of many factors with multiple forms. As the result of the contextualising all factors, one of the four different learning styles are accepted to be the dominant style of the student. In other words, individual actually has all four learning styles, however, one of these learning styles is more dominant in the individual and the others remain as non-dominant styles.

Attitudes affect success and vice versa (Aiken, 1980; Aşkar, 1986). Also, it has been stated in the various researches conducted (Başar, Ünal \& Yalçın, 2002) that math class leads the classes in which students have anxiety and worry. So, it may contribute to remove the negative attitude of students toward mathematicss to determine the factors forming the attitudes of students to math class and to show the relations with the variables related with these factors. For example, in some research (Baykul, 2005; Özdemir, Akgün \& Duru, 2005) it has been reported that negative mathematics experiences of students and their failures in math may cause them to develop negative attitude toward mathematicss. So, it requires examination of the learning process to be able to determine the factors forming the attitudes of students and variables related with these factors.

\subsection{Explore Importance of the Problem}

In various researches conducted (Başar, Ünal \& Yalçın, 2002), it is stated that math leads the lessons in which students have anxiety and worry. These anxiety and worry affect the attitude of students to math class. On the other hand, it is stated by Aiken (1980) and Aşkar (1986) that attitude affects success and vice versa. So, it may affect the attitude of the students toward math class that teachers determine the suitable teaching strategy for students to learn, teaching method and techniques, and required teaching materials. In some researches conducted (Baykul, 2005; Özdemir, Akgün \& Duru, 2005), it is stated that negative mathematic experiences of students and their failures in math may cause them to develop negative attitude toward mathematics. So, it may contribute to remove the negative attitude of students toward mathematics to determine the factors forming the attitudes of students to math class and to show the relations with the variables related with these factors. So, it requires examination of the learning process to be able to determine the factors forming the attitudes of students toward mathematics and variables related with these factors. One of these factors may be the learning styles.

Determining the learning styles of students may help teachers in determining the teaching strategies which they can use, teaching method and techniques, and requires teaching materials, because it is very important to determine learning strategy of individuals for learning and teaching activities. If it is determined what the learning styles of individuals are, it may be more easily understood how the individuals learn and what kind of teaching design is required to be applied (Babadoğan, 2000). So, teacher may establish learning environments suitable for teaching activities. Also, it is a step to 
be taken in order to remove the individual differences among students that teachers pay attention to learning styles of students. Thus, it may be ensured that teachers know the characteristics of students better and they establish a teaching environment in direction of these characteristics. By the way, in the research conducted by Peker and Yalın (2002), it is declared that teachers do not care about the learning style of students much. It is remarked that it is required for teachers to be aware of the learning style of their students and to establish a teaching environment by paying attention to the learning styles of students. So, it is decided to examine the relationship between the learning styles of students and their attitude toward math class which is thought to be one of the most effective variables in attitude. If no research which examine this relationship has been made until not or the quantity and quality of the research conducted is insufficient, it may be stated here with a sentence or two; it shall enrich the reason and importance of this research.

\subsection{Related Literature}

Many studies conducted on learning styles of students or their attitudes are encountered, there are not many studies which reveal the relationship between these two variables.

When researches conducted on learning styles are examined, it has been seen that a part of these researches are those examining the relationship between the learning styles of students and their success. In some of these researches (Burke \& Dunn, 2002; Kopsovich, 2003), it is resulted that learning environment arranged according to the learning style increases the success of student. In some researches (Blanch-Payne, 2000; Ertekin, 2005; Rao, 2000), it has been reported that learning styles have no effect on the success of the student. One of these researches is the one conducted by Dunn (1990). At the end of this research in which the effect of learning styles of students on their attitudes and successes, it has been claimed that students preferring to learn alone are more successful compared to the students who prefer learning together. Koç (2007) has determined at the end of the study in which Koç has examined the relationship between the learning styles of primary education students and their attitude and success toward science that there is no change in the attitude of students based on their styles.

\subsection{State Hypotheses and Their Correspondence to Research Design}

In this research, it has firstly been aimed to determine eighth grade students' learning styles and attitudes toward math class and then, to show the relationship between their learning styles and attitudes toward math class. On this purpose, answer is looked for the research problems given below:

1. How is the distribution of learning styles of eighth grade students like?

2. How is the attitude of eighth grade students toward math class?

3. Is there a reasonable relationship between the learning styles of students and their attitudes to math class?

In this research conducted, it has been aimed to examine the relationship between the learning styles of eighth grade students and their attitude toward math class apart from the other researches conducted. So, it is especially considered that the research shall contribute the area.

\section{Methodology}

\subsection{Research Model}

In this research, it shall be tried to reveal the relationship between the learning styles of eighth grade students and their attitude toward math class by using relational screening model. In this model, it is aimed to determine the alteration existence or grade of two or more variables and variables in which relationship shall be looked for are symbolized. Within this context, relationship between the variables may be in mutual or partial dependence as well as it may be because of another variable affecting these variables (Karasar, 2005).

\subsection{Participant}

This research has been conducted with 100 students who have been volunteers and educated in the eighth grades of a primary school determined with the random sampling method which is one of the probability-based sampling method from the primary schools in one of the metropolitan municipalities in Central Anatolia in Turkey in fall semester of 2014-2015 academic year. In the random sampling method, samples are picked with completely random method (Yıldırım \& Şimşek, 2005). Students having participated in the research are randomly determined and so it has been aimed to act neutrally in picking students.

\subsection{Instruments}

Two different quantitative measurement tools have been used in this research.

One of these measurement tools is Kolb Learning Style Inventory developed by Kolb (1985) and adopted to Turkish by Aşkar and Akkoyunlu (1995) in order to determine eighth grade students' learning styles. This inventory shows that which learning style is more suitable for the individual. 
Other measurement tool taken into research scope is the Attitude Scale toward Math Class developed by Aşkar (1986) in order to determine the attitudes of students toward math class. This scale is the one prepared in type of 5 point likert scale. There are 20 articles in the scale of which 10 are negative and 10 are positive. The maximum score which can be gained from the scale is 100 and the lowest score is 20 points.

\subsection{Data Collection and Analysis}

Data of this research is obtained by application of Attitude Scale toward Math Class and Kolb Learning Style Scale to the students at the eighth grade determined in the 2014-2015 academic year in company with math teachers. Completion of these scales by the students has lasted approximately 40 minutes. Data reached are converted into numerical data and SPSS 14.0 and Excel 2007 packaged software have been used in analyses of the data. Within the scope of analysis of data, frequency and percentage distributions have been calculated in order to determine what kind of distribution show in terms of their learning styles and their attitude.

In this stage, data obtained from the answers given to the articles in Attitude Scale toward Math Class are scored through 5 degrees determined the ends of "never" and "always" and total scores are reached. Then, average scores are reached by dividing the total scores by the number of articles in the attitude scale of the participant students. Range of in-group points are determined in order to be able to interpret the average scores. Within this scope, group range coefficient value is calculated "by division of the difference between the highest value and the lowest value in the series of measurement results by the number in group determined (Kan, 2009: 407)". Accordingly, assessment range in interpretation of answers given by the participant students to the scales are determined as (5-1)/5=0.80. Consequently, ranges for interpretation of answers given by the participant students to the Attitude Scale toward Math Class are described as 4.21-5.00 very high, 3.41-4.20 high, 2.61-3.40 medium, 1.81-2.60 low and 1.00-1.80 very low. Also, Cronbach alpha coefficient calculated for the data obtained within this research for this scale is calculated as .95. It is generally considered sufficient for reliability of test scores that the reliability coefficient calculated for a test is .70 or higher (Büyüköztürk, 2010). This situation shows that measurement scores are sufficient for this measurement tool taken in the scope of research.

In Learning Style Inventory, four learning styles mentioned in the learning style model are defined. Inventory consists of twelve materials with four choices demanding for individuals to sort the four learning styles which describe their learning styles best. Each choice represents four learning styles. They are: Concrete Experience (CE), Reflective Observation (RO), Abstract Conceptualization (AC), and Active Experimentation (AC). A score between 12 and 48 is gained as the result of the scores given by the each answered choice. Combines points are calculated after this scoring. Combined scores are obtained in form of Abstract Conceptualization (AC) - Concrete Experience (CE), and Active Experimentation (AE) - Reflective Observation (RO) and scores obtained as the result of this process vary between -36 and +36 . Positive score obtained with AC-CE shows that learning is abstract and negative score shows that learning is concrete and scores obtained with AE-RO show that learning is active or reflecting. When combines points are placed on the coordinate system, score obtained with the process for AE-RO is shown on axis-X and score obtained with the process of AC-CE is shown on axis-Y. The area in which these two points intersect shows the learning style of the individual.

Then, it has been shown with the Chi-Square $\left(\mathrm{X}^{2}\right)$ test whether there is a reasonable relationship between the learning styles of eighth grade students and their genders and between their attitude level to math class and their genders. In the similar way, Chi-Square $\left(\mathrm{X}^{2}\right)$ test has been applied to determine whether there is a reasonable difference between double-classification variables (learning style and attitude toward math class).

\section{Results}

In this section, findings reached as the result of the application of scales applied to the eighth-grade students are presented. Within this scope, findings of the sub-problems given for the aim of the research are presented in form of tables. Findings obtained regarding with the learning styles of students are given in the Table 1.

Table 1. Percentage and frequency values regarding with the learning styles according to the gender

\begin{tabular}{lcccccc}
\hline & \multicolumn{6}{c}{ Gender } \\
\cline { 2 - 7 } Learning Styles & \multicolumn{2}{c}{ Female } & \multicolumn{2}{c}{ Male } & \multicolumn{2}{c}{ Total } \\
\cline { 2 - 7 } & $\mathrm{f}$ & $\%$ & $\mathrm{f}$ & $\%$ & $\mathrm{f}$ & $\%$ \\
\hline Converging & 13 & 27.7 & 10 & 18.9 & 23 & 23.0 \\
Assimilating & 18 & 38.3 & 20 & 37.7 & 38 & 38.0 \\
Diverging & 11 & 23.4 & 9 & 17.0 & 20 & 20.0 \\
Accommodating & 5 & 10.6 & 14 & 26.4 & 19 & 19.0 \\
\hline Total & 47 & 47.0 & 53 & 53.0 & 100 & 100.0 \\
\hline
\end{tabular}

In the examinations made, it has been understood that $27.7 \%$ of female students have converging, $38.3 \%$ have 
assimilating, $23.4 \%$ have diverging, and $10.6 \%$ have accommodating learning style. In the same way, $18.6 \%$ of the male students whose learning styles are detected have converging, 37.7\% have assimilating, $17 \%$ have diverging and $26.4 \%$ have accommodating learning style. Also, it is seen that majority of female students (38.8\%) and male students (37.7\%) have assimilating learning style. By the way, while the least number of female students (10.6\%) is having accommodating learning style, the least number of male students (17\%) has diverging learning style. When total value reached is examined, it has been seen that the learning style adopted least is accommodating, while an important part of the students having participated in the research (38\%) has assimilating learning style. The analysis indicates that there is a relationship between the learning styles and the genders of students. In Table 2, findings obtained regarding with the attitudes of students are presented.

Table 2. Percentage and frequency of attitude of eighth-grade students toward math class

\begin{tabular}{lccrrrr}
\hline & \multicolumn{3}{c}{ Gender } & \multicolumn{2}{c}{ Total } \\
\cline { 2 - 7 } Attitude levels & \multicolumn{1}{c}{ f } & \multicolumn{1}{c}{ Male } & \multicolumn{1}{c}{ f } & $\%$ & \multicolumn{1}{c}{ f } & $\%$ \\
\hline Very low & 0 & 0.0 & 2 & 3.8 & 2 & 2.0 \\
Low & 3 & 6.4 & 3 & 5.7 & 6 & 6.0 \\
Medium & 9 & 19.1 & 15 & 28.3 & 24 & 24.0 \\
High & 16 & 34.0 & 20 & 37.8 & 36 & 36.0 \\
Very High & 19 & 40.5 & 13 & 24.4 & 32 & 32.0 \\
\hline Total & 47 & 100.0 & 53 & 100.0 & 100 & 100.0 \\
\hline
\end{tabular}

It is seen in the examinations made that attitudes of $36 \%$ of students toward math class are high, attitudes of $24 \%$ of them are very high. In other words, attitudes of half of students having participated in the sampling $(60 \%)$ are detected to be high or very high. In the examination carried out in terms of genders, it has been understood that $74.5 \%$ of female students and $62.2 \%$ of male students have high and very high attitude levels.

In this research, Chi-Square analysis has been conducted in order to research the relationship between the learning style of the students having participated in the research and the attitude level to math class following the analysis of their learning styles and their attitudes toward math class. Result of this analysis conducted is presented in the following Table 3.

Table 3. Result of Chi-Square analysis researching the relationship between the attitudes and their learning styles

\begin{tabular}{lcrrrrr}
\hline & & \multicolumn{4}{c}{ Learning Styles } & \\
\cline { 2 - 6 } \multicolumn{1}{c}{ Attitude levels } & Accommodating & Converging & Diverging & Assimilating & Total \\
\hline Very Low & $\mathrm{n}$ & 1 & 0 & 0 & 1 & 2 \\
& $\%$ & 4.3 & 0.0 & 0.0 & 6.3 & 2.1 \\
\hline Low & $\mathrm{n}$ & 3 & 3 & 0 & 0 & 6 \\
& $\mathrm{n}$ & 13.0 & 7.9 & 0.0 & 0.0 & 6.2 \\
\hline Medium & $\mathrm{n}$ & 5 & 6 & 3 & 10 & 24 \\
& $\mathrm{n}$ & 21.7 & 15.8 & 15.0 & 62.5 & 24.7 \\
\hline High & $\%$ & 39.1 & 18 & 6 & 0 & 33 \\
& $\mathrm{n}$ & 5 & 11.4 & 30.0 & 0.0 & 34.0 \\
\hline Very High & $\mathrm{n}$ & 21.7 & 28.9 & 55.0 & 5 & 32 \\
& $\mathrm{n}$ & 23 & 38 & 20 & 31.3 & 33.0 \\
\hline Total & $\%$ & 100.0 & 100.0 & 100.0 & 16 & 97 \\
& & & & & 100.0 & 100.0 \\
\hline
\end{tabular}

Chi-Square $\left(\mathrm{X}^{2}\right)=30.323 \quad \mathrm{sd}=12 \quad \mathrm{p}=0.002$

When Table 3 is examined, it is seen that there is a reasonable relationship between the learning styles of the students having participated in the research and their attitude toward math class $\left(X^{2}=30.323 ; p=0.002\right)$. As can be understood from the Table 3, it has been seen that students whose attitudes to math class is high and very high are majorly those having assimilating and diverging learning style.

\section{Conclusions and Discussion}

In the examinations made within the scope of this research, it has been understood that students having education at eighth grade and participated in the research have assimilating learning style most and accommodating learning style least. In the detailed examination carried out, it has been revealed that both female students and male students have the assimilating learning style. By the way, while the least number of female students is having accommodating learning style, the least number of male students has diverging learning style. When total value reached is examined, it has been seen that the learning style adopted least is accommodating, while an important part of the students having participated in the research has assimilating learning style.

As the result of the examination carried out through the attitude of students having participated in the research toward 
math class, it has been understood that attitudes of more than half of students toward math class are high and very high. Also, it has been seen that the attitude levels of majority of female students and more than half of male students toward math class are high and very high.

Also, as the result of the correlation analysis conducted, medium level of relationship between the learning styles of the eighth-grade students having participated in the research and their genders and high level of relationship between the their attitude levels toward math and their gender are reached. By the way, as the result of the analysis conducted, it has been seen that students whose attitudes toward math class are high and very high are those mostly having converging and diverging learning style. Also the results of chi-square analysis conducted have indicated learning styles of eighth-grade students having participated in the research and their attitude levels toward math class are related.

When it is considered that individuals having assimilating learning style prefer audible, visual and lecturing and they are focused in the area of mathematics, results of the research support it. As can be understood from the results, there are individuals having different learning styles not a single learning style in a class environment. So, it is important to give place to activities and applications for each teaching strategy and it is required that the learning styles of students are known by the teacher, because, in case that lectures are given to individuals having different learning styles in compliance with their learning styles, their attitude toward math class and, in paralleled way, math class success may increase.

\section{Implications}

These suggestions may be presented in direction of the results reached within the scope of this research:

-Teachers may have knowledge about the characteristics of students in their classes by application of learning style inventory and easily detect the required teaching models and required materials.

-Teachers may establish teaching environment by considering all learning styles not a single-type learning style.

-Mathematic classes may be established in schools and these classes may be enriched with visual materials.

-Required educations may be given to teachers in relation with the learning styles and teaching methods in compliance with the learning styles.

\section{References}

Aiken L. R. (1980). Attitudes toward mathematicss. Review of Educational Research, 40.

Akgün, L. (2002). Matematiğe karşı olumlu tutum geliştirme faktörleri (Unpublished doctoral dissertation). Atatürk University Institute of Science, Erzurum, Turkey.

Akkoyunlu, B. (1995). Bilgi teknolojilerinin okullarda kullanımı ve öğretmenlerin rolü. Hacettepe University Journal of Education, 11, 105-109.

Aşkar, P. (1986). Matematik dersine yönelik tutum ölçen likert tipi bir ölçeğin geliştirilmesi. Eğitim ve Bilim, 11(62).

Aşkar, P., \& Akkoyunlu, B. (1993). Kolb Öğrenme Sitili Envanteri. Eğitim ve Bilim, 87, 37-47.

Babadoğan \& Babadoand, C. (2000). Öretim Stili Odaklı Ders Tasarımı. Millî Eğitim Dergisi, 147. http://yayim.meb.gov.tr/yayimlar/147/babadogan.htm.

Başar, M., Ünal, M., \& Yalçın, M. (2002). lköretim Kademesiyle Başlayan Matematik Korkusunun Nedenleri. The $5^{\text {th }}$ National Science and Mathematics Education Congress, METU, Ankara, Turkey.

Baykul, Y. (2005). Ilkögrretimde matematik öğretimi (The $8^{\text {th }}$ Edition). Ankara, turkey: Pegem.

Blanch-Payne, E. (2000). Teaching styles of faculty and learning styles of their students: Congruent versus incongruent teaching styles with regards to academic disciplines and gender. Unpublished doctoral dissertation, Kent State University.

Boydak, A. (2001). Ögrenme stilleri. Istanbul: Beyaz Publications.

Burke, K., \& Dunn, R. (2002). Teaching math effectively to elementary students. Academic Exchange Quarterly, 6(1).

Büyüköztürk, Ş. (2010). Sosyal bilimler için veri analizi el kitabı. Ankara, Turkey: Pegem.

Chen, C. J., Toh, S. C., \& Ismail, W. M. F. W. (2005). A feasible instructional development model for virtual reality(VR)-Based learning environments: Its efficacy in the novice car driver instruction of Malaysia. Educational Technology Research \& Development, 53(1), 111-123. http://dx.doi.org/10.1007/BF02504861

Çoban, A. (1989). Ankara merkez ortaokullarındaki son sınıf öğrencilerinin matematik dersine ilişkin tutumları. (Unpublished Master Thesis). Gazi University, Institute of Social Sciences, Ankara, Turkey. 
De Bello, T. C. (1990). Comparison of eleven major learning styles models: variables, appropriate populations, validity of instrumentation and the research behind them. Journal or Reading, Writing, and Learning Disabilities, 6, 203-222. http://dx.doi.org/10.1080/0748763900060302

Dunn, R. (1990). Answers questions on learning styles. Educational Leadership, 48(2), 15-19.

Ertekin, E. (2005). Öğrenme stilleri üzerine bir çalışma. Selçuk University Journal of Education, 19, 389-402.

Hall, A. L. (1993). A critical exploration of learning style preferences and the mathematical achievement of chapter 1 middle school students' administrative and instructional implications (Unpublished doctoral Dissertation). Oklahama State University, OK, United States of America.

Kan, A. (2009). Ölçme sonuçları üzerinde istatistiksel işlemler. H. Atılgan (Ed.), Eğitimde ölçme ve değerlendirme (ss.397-456). Ankara: Anı Publications.

Kapsovich, \& Kopsovich, R. D. (2003). A study of correlations between learning styles of students and their mathematics scores on the Texas assessment of academic skills test. Unpublished doctoral dissertation, University of North Texas.

Karasar, N. (2005). Bilimsel arastirma yontemi (Scientific research methods) (15th edition).Ankara, Turkey: Nobel Publications.

Koç. D. (2007). İlköğretim ögrencilerinin öğrenme stilleri: fen başarısı ve tutumu arasındaki ilişki (Unpublished Doctoral Dissertation). AfyonKocatepe University, Institute of Socaial Sciences, Afyonkarahisar, Turkey.

Kolb, D. A. (1984). Experiential learning: Experience as the source of learning and development. New Jersey, NJ: Prentice Hall.

McCarthy, B. (1987). The 4MAT system: Teaching to learning styles with right/left mode techniques. Barrington: Excel Inc.

Öcalan, T. (2004). Ilköğretimde matematik öğretimi. Ankara, Turkey: Yeryuzu Publications.

Özdemir, M. E., Duru, A., \& Akgün, L. (2005). İki ve üç boyutlu düşünme: iki ve üç boyutlu geometriksel şekillerle bazi özdeşliklerin görselleştirilmesi. Kastamonu Journal of Education, 13(2), 527-540.

Peker, M., \& Mirasyedioğlu, Ş. (2003). Lise 2. sınıf öğrencilerinin matematik dersine yönelik tutumları ve başarıları arasındaki ilişki. Pamukkale University Journal of Education, 14(2), 157-166.

Peker, M., \& Yalın, H. İ. (2002). Matematik öğretmenlerinin öğrencilerin öğrenme stil/erine uygun öğretim yapma düzeyleriyle ilgili öğrenci görüşleri. V. Ulusal Fen Bilimleri ve Matematik Eğitimi Kongresi.

Rao, N. (2000). Motivational beliefs, study strategies and mathematics attainment in high- and low-achieving Chinese secondary school students. Contemporary Educational Psychology, 25, 287-316. http://dx.doi.org/10.1006/ceps.1999.1003

Ülgen, G. (1994). Ë̌itim psikolojisi: Kavramlar, ilkeler, yöntemler, kuramlar ve uygulamalar. Ankara, Turkey: Lazer Ofset.

Yıldırım, A., \& Şimşek, H. (2005). Sosyal bilimlerde nitel araştırma yöntemleri (The $5^{\text {th }}$ Publication). Ankara, Turkey: Seckin Publications.

\section{$(\mathrm{oc}) \mathrm{BY}$}

This work is licensed under a Creative Commons Attribution 3.0 License. 